\title{
27. ORGANIC GEOCHEMICAL STUDIES OF SAMPLES FROM DEEP SEA DRILLING PROJECT LEG 64, GULF OF CALIFORNIA: SITES 474, 477, 478, 479, AND 481
}

\author{
E. M. Galimov, L. A. Kodina, M. P. Bogacheva, and V. G. Shirinsky, Vernadsky Institute of Geochemistry and \\ Analytical Chemistry, Academy of Sciences of the U.S.S.R., Moscow, U.S.S.R.
}

\begin{abstract}
Twenty-six core samples from Leg 64 , Holes 474, 474A, 477, 478, 479, and 481A in the Gulf of California, were provided by the Joint Oceanographic Institutions for Deep Earth Sampling (JOIDES) Advisory Panel on Organic Geochemistry for analysis. The high heat flow characteristic of the basin provides an opportunity to study the effect of temperature on the diagenesis of organic matter. The contents and carbon isotope compositions of the organic matter and bitumen fractions of different polarity, isoprenoid and normal alkane distributions, and the nature of tetrapyrrole pigments were studied. Relative contents of hydrocarbons and bitumens depend on the thermal history of the deposits. Among other criteria, the nature and content of tetrapyrrole pigments appear to be most sensitive to thermal stress. Whereas only chlorins are present in the immature samples, porphyrins, including VO-porphyrins, appear in the thermally altered deposits, despite the shallow burial depth. Alkane distributions in thermally changed samples are characterized by low values of phytane to $n-C_{18}$ ratios and an odd/even carbon preference index close to unity. The thermally altered samples show unusual carbon isotope distributions of the bitumen fractions.

The data also provide some evidence concerning the source of the organic matter and the degree of diagenesis.
\end{abstract}

\section{INTRODUCTION}

Core samples were studied from Holes $474,474 \mathrm{~A}$, $477,478,479$, and $481 \mathrm{~A}$ in the Gulf of California (for site locations, see the introduction to the organic geochemistry section, this volume). The samples provide a unique opportunity to study the effect of temperature on the diagenesis of sedimentary organic matter of $\mathrm{Re}$ cent geologic age. The activities of recent tectonic processes generate extremely diversified thermal conditions within the sedimentary basin.

Holes 474 and $474 \mathrm{~A}$ were drilled at the base of the continental slope, $55 \mathrm{~km}$ southeast of the tip of Baja California (water depth $=3022-3023 \mathrm{~m}$ ). Site 474 is on ocean crust overlain by about 500 meters of mainly diatomaceous mud and mudstone turbidites. Hole 474 was cored to 182.5 meters and Hole $474 \mathrm{~A}$ to 626 meters. Sediments are penetrated by two dolerite sills at the bottom of the hole. The heat flow is 3.1 units $\left(\mu \mathrm{cal} \mathrm{\textrm {cm } ^ { - 2 }}\right.$ $\mathrm{s}^{-1}$ ).

Hole 477 is in the Guaymas Basin, an actively spreading ocean basin that includes two spreading rifts. Hole 477 was drilled to 191 meters in the southern rift (water depth $=2003 \mathrm{~m}$ ). The sediments are late Quaternary diatom ooze and turbidites intruded by a dolerite sill from 58-105.5 meters. Dolomite, anhydrite, and pyrite occur below the sill. Mineral paragenesis includes epidotes, quartz, albite, and chlorite. These hydrothermal minerals indicate temperatures up to $300^{\circ} \mathrm{C}$ (Einsele et al., 1980). The heat flow in the hole has a value of about 20 units. A major heat source appears to be below the drilled section.

Hole 478 is $12 \mathrm{~km}$ from Site 477 and outside the present rift zones in the transform fault zone (water depth =

\footnotetext{
${ }^{1}$ Curray, J. R., Moore, D. G., et al., Init. Repts. DSDP, 64: Washington (U.S. Govt. Printing Office).
}

$1889 \mathrm{~m})$. The sub-bottom depth is 464 meters. Several sill intrusions occur in the sediments, but the heat flow is lower (3.65 units) than in Hole 477. The oldest sediments are late Pleistocene.

Hole $481 \mathrm{~A}$ was drilled in the southwestern part of the northern rift of Guaymas Basin at a water depth of 1998 meters; drilling terminated at 364 meters sub-bottom. The heat flow value is about 4 units. The oldest sediments are late Quaternary diatomaceous ooze and mudstones. Several sills penetrated the sediments at 169$197,328-333,350-363$, and $365-366$ meters. The temperature in this hole should not have exceeded $150^{\circ} \mathrm{C}$ (Einsele et al., 1980).

Hole 479 lies on the northwest continental slope of the Guaymas Basin at a water depth of 747 meters. The hole penetrated 440 meters into a sequence of diatomaceous ooze to laminated mudstones. This site lies in the oxygen-minimum zone and has a high sedimentation rate. The heat flow was measured at 2.36 units.

\section{METHODS}

Core samples $(70-300 \mathrm{~g}$; average $=150 \mathrm{~g})$ were obtained unfrozen in airtight plastic packets, which precluded cleaning the samples by removing the outer surface layers. Samples were placed in glass dishes, air-dried, ground in an agate mortar, sifted through a 60-mesh sieve, and then used for preparation and analysis. The method of separation, fractionation, and analysis of the organic matter is described in Galimov et al. (1980).

\section{Separation and Fractionation of Bitumen}

Dry core samples were exhaustively extracted in a Soxhlet apparatus with benzene-methanol $(9: 1)$. Coextracted inorganic salts were removed by washing the dry residues with distilled water; elemental sulfur was removed with activated $\mathrm{Cu}$ foil. The bitumen extracts were then evaporated, air-dried, and weighed.

The extracts were colorless (Sections 481A-13-6, 477-16-5, 477-71), light yellow (Section $474 \mathrm{~A}-40-3$ ), or bright green (Sections $478-2-5$, 478-13-2) to dark brown (Sections 481A-30-5, 478-28-4).

Asphaltenes were precipitated from the bitumen solutions in benzene by a 50 -fold volume excess of pentane. The precipitates were separated by filtering them through an N4 sintered glass filter. The 
pentane solutions were fractionated on silica gel columns by using the solvent mixtures for elution in the following sequence: hexane-benzene (1:1), benzene, and benzene-methanol (1:1), producing corresponding bitumen fractions. The hexane fractions contain hydrocarbons, which are brightly luminescent and light yellow. The fractions were evaporated and then air-dried at $40^{\circ} \mathrm{C}$. The next three fractions contain hexane-benzene, benzene, and benzene-methanol soluble resins, which differ from each other by their polarity. The hexane-benzene fractions are often pinkish or orange owing to the presence of $\mathrm{Ni}$ porphyrins. The benzene fractions are the smallest and are light yellow or sometimes reddish because of the presence of other metalloporphyrin complexes. The benzene-methanol resins-the predominant fractions of the pentane solubles-are dark brown or greenish brown. The resin fractions were rotoevaporated at $40^{\circ} \mathrm{C}$ and air-dried at room temperature.

\section{Gas Liquid Chromatography}

The hexane fractions were analyzed by gas chromatography. A copper capillary column containing Apiezon L was used. The distribution data on $n$-alkanes and the isoprenoid alkanes pristane and phytane were determined. For details of the chromatographic procedure see Galimov et al. (1980).

\section{Visible Light Spectroscopy}

To trace the different forms of tetrapyrrole pigments, absorption spectra of some bitumen fractions (especially hexane-benzene) in the visible region from 320 to $700 \mathrm{~nm}$ were recorded on an SF-8 recording spectrophotometer. The electron spin resonance (ESR) spectra of hexane-benzene and benzene fractions for several core samples were also recorded. Aliquots of bitumen without $\mathrm{Cu}$ treatment were used for recording spectra.

\section{Isotopic Analysis of Carbon}

The isotopic compositions of carbon for total bitumen, all the bitumen fractions, and the total organic matter after treatment with hydrochloric acid were determined as carbon dioxide. The measurements were made on a Varian-MAT-230 mass spectrometer. The reproducibility of the experimental results, including the full sequence of separation and fractionation of organic matter and preparation of samples for isotopic analysis and measurements, does not exceed an average of $\pm 0.2 \%$.

\section{RESULTS}

\section{The Content and Components of Organic Matter}

\section{Total Organic Matter}

Organic carbon content data are presented in Table 1 and Figure 1. The sediments are characterized by the rather high organic carbon content-from 0.16 to $2.7 \%$, with an average of about $1.5 \%$. The highest value occurred in the sediments of Hole 479 (average $1.84 \%$ and varying from 1.04 to $2.17 \%$ ). Although the organic carbon $\left(\mathrm{C}_{\mathrm{org}}\right)$ content throughout the profiles varies to some extent, it is rather uniform, except for a distinct drop in the samples near sills, interpreted to be due to their thermal effect.

\section{Bitumen}

The variations of bitumen content in the sequence of Hole 474 are 165 to $1786 \mathrm{ppm}$; in Hole 477, from 87 to $1840 \mathrm{ppm}$; in Hole 478, from 192 to $3163 \mathrm{ppm}$; and in Hole 481A, from 97 to 2550 ppm (Fig. 1, Table 1).

When normalized to the organic carbon content, the amount of bitumen varies from $1.22 \%$ to $36.36 \%$ (Fig. 2 ). The highest bitumen percentage (Fig. 1) as well as the amount of bitumen normalized to $\mathrm{C}_{\mathrm{org}}$ content (Fig. 2) was found in Section 477-7-1, 8 meters above the sill. There were very low bitumen contents in two Sections
(477-16-5, 477-20-1) affected by strong thermal stress and in Section 481-13-6, about 5 meters from a sill and dramatically influenced by that intrusive body. Similar effects were reported previously by Simoneit et al. (1978), Perregaard and Schiener (1979), and Dow (1978).

\section{Bitumen Components}

The concentrations of bitumen components are given in Figure 3 and Table 1. Asphaltenes are clearly predominant. Asphaltene contents for the majority of samples vary from 42 to $73 \%$ of the whole extract, except for four sections: 477-16-5, 477-20-1, 474A-40-3, and 481A-13-6. Asphaltene concentrations in these sections are only 9 to $28 \%$ of the bitumen. Hexane fractions (hydrocarbon) contents vary from 2 to $50 \%$ of the bitumen (Fig. 3) and from 0.18 to $4.77 \%$ when normalized to the $\mathrm{C}_{\mathrm{org}}$ content (Fig. 2). In most sections the hexane fraction amounts to 3 to $7 \%$ of the bitumen, and reaches 10 to $20 \%$ for some sections (474A-40-3, 477-7$1,478-35-5,479-43-1)$ because of the proximity of sills. Strong thermal stress causes hydrocarbons to dominate the bitumen fraction (up to $50 \%$ in Sections 477-16-5, 477-20-1, and 481A-13-6; Fig. 3). When normalized to $\mathrm{C}_{\text {org }}$ content, the hydrocarbon content in these thermally stressed sections, however, is lower than in samples not severely heated by the sills (in Sections $474 \mathrm{~A}-40-3$, 477-7-1, 478-35-5, and 479-43-1).

\section{n-Alkanes, Isoprenoids}

The results of gas chromatographic analyses of the hexane fractions of the bitumens are listed in Table 2, shown in Figure 4, and plotted as diagrams of concentration versus depth in Figures 5 through 9.

\section{Tetrapyrrole Pigments}

The data on the distribution of tetrapyrrole pigments throughout all the sections, based on the visible light spectra of the bitumen fractions, are listed in Table 3 . Obviously, there are different types of tetrapyrrole pigments present. In the uppermost cores of Hole 478 (Sections 2-5, 6-3, 9-2) and in Sections 477-5-1 and 481-2-2 chlorins are present with absorption bands at 600 and $650 \mathrm{~nm}$. Down section the chlorins gradually change to porphyrins, especially Ni-complexes (Fig. 10, spectrum a). It is noteworthy that a trace of Ni-porphyrins is present in Section 474-2-3, 6 meters sub-bottom (Fig. 10, spectrum b). Section 477-7-1, 8 meters above the sill (Fig. 10, spectrum d), contains, in addition to Ni-porphyrins, Cu-complexes with a specific band of $562 \mathrm{~nm}$. The presence of a considerable amount of Cu-porphyrins in the hexane-benzene bitumen fraction of this core was confirmed by ESR spectroscopy.

In the benzene fraction of the bitumen from Section 477-7-1, vanadyl complexes of porphyrins were detected by their specific bands at 530 and $570 \mathrm{~nm}$, using lightvisible spectroscopy, as well as by ESR spectroscopy. In Sections 477-16-5 and 477-20-1 the tetrapyrrole pigments have completely disappeared (Fig. 11). The effect of thermal degradation of porphyrins influenced by sill intrusions was cited earlier (Baker, Palmer, and Huang, 1978). 
Table 1. Organic carbon, bitumen, and bitumen components.

\begin{tabular}{|c|c|c|c|c|c|c|c|c|c|}
\hline Section & $\begin{array}{l}\text { Sub-bottom } \\
\text { Depth } \\
\text { (m) }\end{array}$ & $\begin{array}{l}C_{\text {org }} \\
(\%)\end{array}$ & $\begin{array}{c}\text { Total } \\
\text { Bitumen } \\
\text { in Sediment } \\
(\mathrm{ppm})\end{array}$ & $\begin{array}{c}\text { Bitumen } \\
\text { Relative } \\
\text { to } \mathrm{C}_{\text {org }} \\
(\%)\end{array}$ & $\begin{array}{c}\text { Hexane } \\
(\mathrm{ppm})\end{array}$ & $\begin{array}{c}\text { Hexane- } \\
\text { Benzene } \\
\text { (ppm) }\end{array}$ & $\begin{array}{c}\text { Benzene } \\
(\mathrm{ppm})\end{array}$ & $\begin{array}{l}\text { Benzene- } \\
\text { Methanol } \\
\text { (ppm) }\end{array}$ & $\begin{array}{c}\text { Asphaltenes } \\
\text { (ppm) }\end{array}$ \\
\hline \multicolumn{10}{|c|}{ Hole 474} \\
\hline $2-3$ & $6.2-6.5$ & 2.52 & 1786 & 7.07 & 188 & 33 & 72 & 585 & 910 \\
\hline $6-5$ & $46-46.3$ & 0.97 & 376 & 3.89 & 36 & 36 & 14 & 130 & 159 \\
\hline $17-6$ & $153-153.25$ & 0.53 & 832 & 15,76 & 58 & 60 & 53 & 297 & 363 \\
\hline \multicolumn{10}{|c|}{ Hole 474A } \\
\hline $21-6$ & $351.98-352.28$ & 1.10 & 579 & 5.29 & 33 & 22 & 14 & 250 & 260 \\
\hline $40-3$ & $528.7-529.0$ & 0.16 & 165 & 10.30 & 32 & 21 & 9 & 55 & 47 \\
\hline \multicolumn{10}{|c|}{ Hole 477} \\
\hline $5-1$ & $30.7-30.9$ & 2.02 & 1840 & 9.11 & 83 & 52 & 23 & 568 & 1110 \\
\hline $7-1$ & $49.82-49.92$ & 0.94 & 3414 & 32.26 & 450 & 81 & 151 & 716 & 2010 \\
\hline $16-5$ & $121.58-121.88$ & 0.61 & 87 & 1.43 & 44 & 10 & 12 & 15 & 7 \\
\hline $20-1$ & $154.15-154.25$ & 0.82 & 100 & 1.22 & & & 7 & & 13 \\
\hline \multicolumn{10}{|c|}{ Hole 478} \\
\hline $2-5$ & $10.7-11.0$ & 2.74 & 3163 & 11.53 & 108 & 137 & 111 & 530 & 2300 \\
\hline $6-3$ & $45.7-46.0$ & 1.38 & 1012 & 7.35 & 81 & 37 & 30 & 232 & 630 \\
\hline $9-3$ & $74.1-74.4$ & 1.49 & 1502 & 9.82 & 33 & 41 & 40 & 450 & 937 \\
\hline $13-2$ & $110.7-111.0$ & 2.17 & 1488 & 6.85 & 68 & 16 & 23 & 450 & 931 \\
\hline $16-4$ & $142.2-142.5$ & 0.95 & 1028 & 10.77 & 32 & 40 & 68 & 206 & 680 \\
\hline $20-4$ & $170.5-170.9$ & 1.08 & 657 & 6.08 & 20 & 15 & 18 & 190 & 413 \\
\hline $28-4$ & $248.2-248.5$ & 1.77 & 1453 & 8.18 & 106 & 42 & 37 & 404 & 862 \\
\hline $35-5$ & $305.1-305.4$ & 0.40 & 192 & 4.75 & 21 & 3 & 4 & 74 & 90 \\
\hline \multicolumn{10}{|c|}{ Hole 479} \\
\hline $9-2$ & $72.15-72.40$ & 2.17 & 1389 & 6.38 & 78 & 36 & 27 & 416 & 830 \\
\hline $19-5$ & $171.6-171.9$ & 1.84 & 1442 & 7.82 & 66 & 26 & 10 & 469 & 809 \\
\hline $27-4$ & $246.25-246.50$ & 2.29 & 1490 & 6.5 & 83 & 25 & 10 & 345 & 1025 \\
\hline $43-1$ & $393.7-393.9$ & 1.04 & 783 & 7.55 & 122 & 35 & 22 & 187 & 417 \\
\hline \multicolumn{10}{|c|}{ Hole 481A } \\
\hline $2-2$ & $57.75-58.0$ & 2.29 & 2550 & 11.12 & 132 & 60 & 30 & 770 & 1550 \\
\hline $4-2$ & $73.10-73.60$ & 1.51 & 2369 & 15.69 & 116 & 30 & 49 & 588 & 1584 \\
\hline $13-6$ & $162.0-162.14$ & 0.56 & 97 & 1.71 & 37 & 17 & 10 & 19 & 17 \\
\hline $24-5$ & $267.6-268.0$ & 0.83 & 520 & 6.27 & 37 & 19 & 14 & 227 & 222 \\
\hline $30-5$ & $324.6-324.9$ & 1.44 & 1350 & 9.37 & 55 & 30 & 47 & 443 & 773 \\
\hline
\end{tabular}

In addition to DPEP- and etio-type Ni-porphyrins in the benzene fractions of some cores, rhodo-type $\mathrm{Ni}$ porphyrins, indicated by the absorption peak at 585 nm (Fig. 10, spectrum c) (Baker, Palmer, and Parrish, 1976), were detected. As a rule this type of absorption curve was observed for samples from sections (478-28-4, 481A-30-5) adjacent to small sills.

It should be mentioned that trace amounts of Cu-porphyrins were identified by ESR spectroscopy in Sections 478-28-4, 479-27-4, and 481A-30-5.

\section{Isotope Composition of Carbon}

The carbon isotope compositions of the total organic matter and the extractable bitumen from all the cores studied are presented in Table 4 and plotted versus depth in Figure 12. The carbon isotope distributions are rather uniform for all the holes. The values of $\delta^{13} \mathrm{C}_{\text {org }}$ range from -20.46 to $-23.35 \%$.

The bitumens are enriched in the light carbon isotope relative to the total organic matter on an average of $2.2 \%$. There is a correspondence between the isotopic composition of the organic matter (virtually kerogen) and that of bitumen. The most isotopically heterogeneous bitumen occurred in the highly heated deposits in Hole 477.
The data on the carbon isotope composition of bitumen fractions summarized in Table 4 are plotted in Fig. 13. There are significant and consistent differences in the carbon isotope compositions of different bitumen fractions. This was also true of Leg 50 samples (Galimov et al., 1980). There is a correlation between the polarity of the bitumen components and the isotopic composition of its carbon. The hexane fractions (hydrocarbon) are most enriched in the light carbon isotope, and asphaltenes are isotopically the heaviest fractions of bitumen. The average value of $\delta^{13} \mathrm{C}_{\text {hydrocarbon }}$ is $-26.55 \%$ and of $\delta{ }^{13} \mathrm{C}_{\text {asphaltenes }},-23.35 \%$, the remaining fractions being intermediate and having more positive values of $\delta^{13} \mathrm{C}$ as the polarity increases.

It should be noted that this isotope regularity does not apply to the bitumen fractions of the thermally stressed sediments (Sections 477-16-5, 477-20-1, and 481A-13-6). As was the case for Leg 50 (Galimov et al., 1980 ), there is a correlation among the isotopic compositions of the bitumen fractions and the isotopic composition of total organic matter of the sediments. It is also noteworthy that the correlation coefficients decrease when the $\delta^{13} \mathrm{C}$ value of total organic carbon is compared with that of asphaltenes, methanol-benzene resins, benzene resins, hexane-benzene resins, and hydrocarbons; 


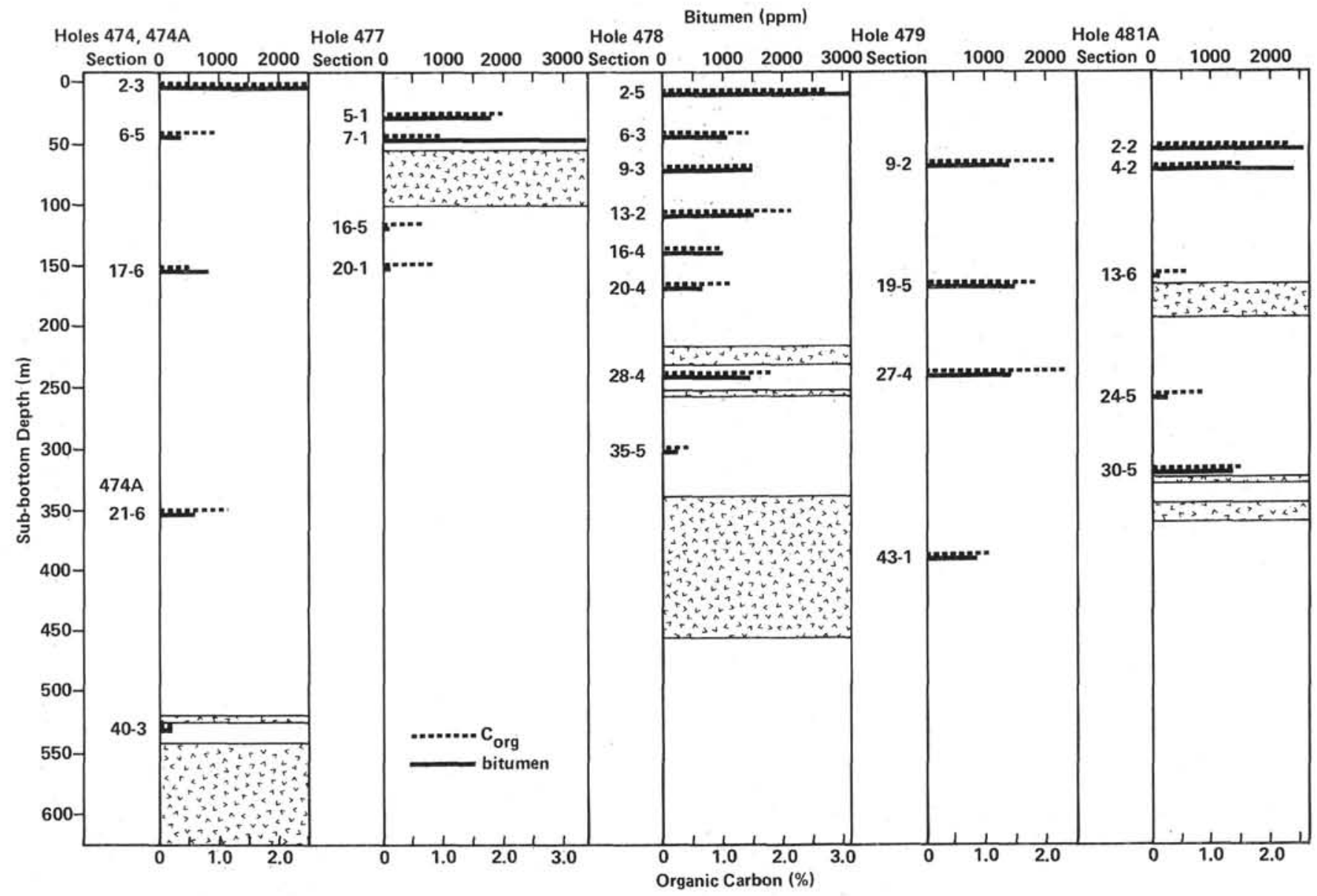

Figure 1. Organic carbon and bitumen in samples from Holes 474, 474A, 477, 478, 479, and 481A.

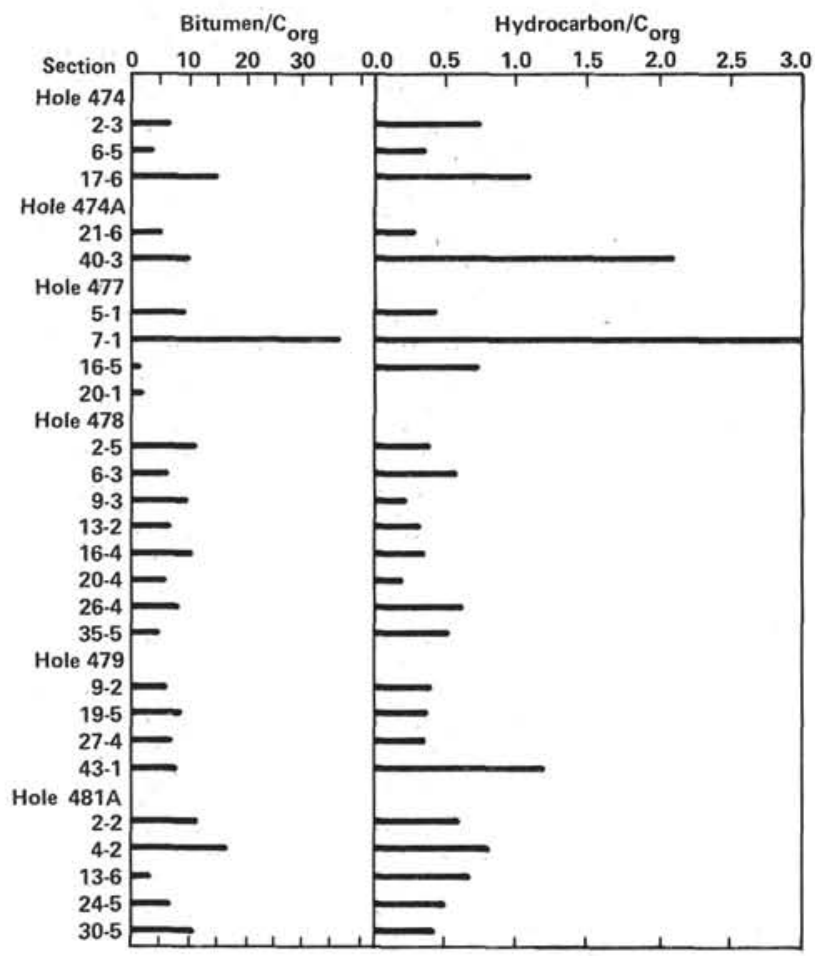

Figure 2. Bitumen and hydrocarbon content normalized to the total organic carbon.

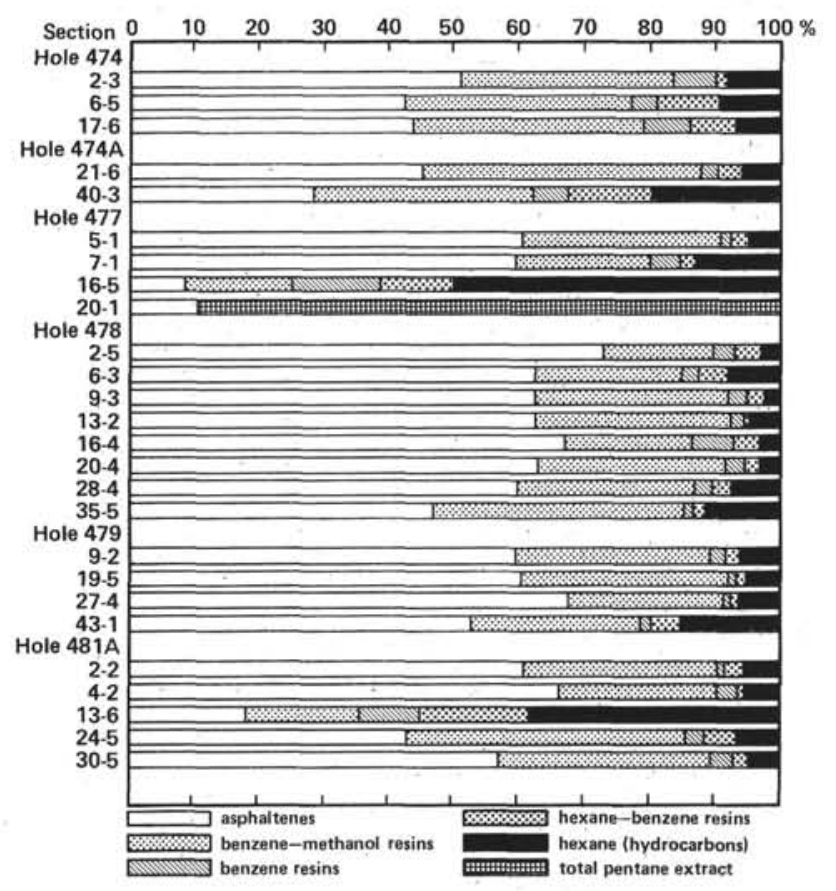

Figure 3. Bitumen components. 
Table 2. Relative content of alkanes.

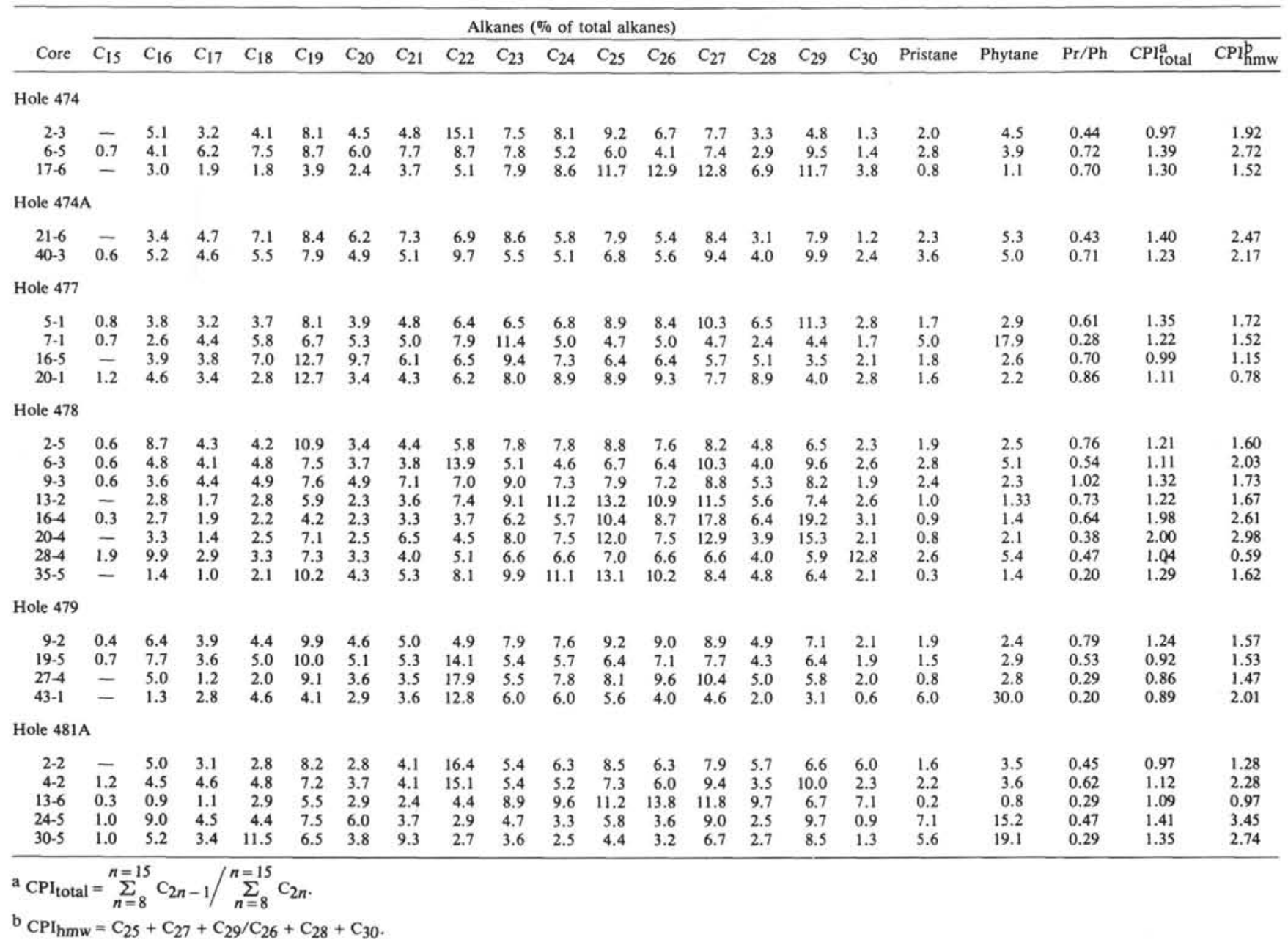

this evidently corresponds to their geogenetic derivation from the initial organic matter (Fig. 14).

\section{DISCUSSION}

\section{Thermal History: Bitumen and Hydrocarbon Contents}

Our results show that the relative contents of the fractions of organic matter and their properties clearly depend on the thermal history of the deposits.

Compositional changes of the bitumens toward higher contents of the nonpolar fractions, especially the hydrocarbon fractions, indicate thermal alteration of the organic matter. The increases of the relative contents of hydrocarbons are appreciable in Sections 474$40-3$, 477-7-1, 477-16-5, 477-20-1, 478-6-3, 478-28-4, $478-35-5,479-43-1$, and $481 \mathrm{~A}-13-6$. The majority of these sections were sampled in close proximity to dolerite sills.

The bitumen coefficient is the amount of extractable organic matter normalized to the organic carbon content; it increases in mature organic matter. The maximum bitumen content occurs in Section 477-7-1. Bitumen contents proved to be much less in Sections 47716-5 and 481A-13-6, whereas the relative hydrocarbon contents were extremely high (Fig. 3). The amounts of hydrocarbon relative to the total organic carbon (Fig.
2) also decrease in Sections 477-16-5 and 481A-13-6, though to a lesser degree than the bitumen coefficient.

The characteristics of the samples are so dependent on thermal history that we can predict an increase in extractability and hydrocarbon content up to a point, followed by a reduction after passing through that maximum. The best agreement with data occurs when the bitumen content increases slowly but drops sharply with an increase in thermal alteration of the organic matter and when the hydrocarbon content increases drastically and then decreases smoothly. The nature of the corresponding curves is shown in Figure 15. The maxima of both curves are probably close to each other. The maximum would be represented by Section 477-7-1. Section 474-40-3 is typical of the ascending part of the curves, and Sections 477-16-5 and 481A-13-6 correspond to the descending part.

Thus the samples from different holes can be considered a representative series typifying thermal effects in various degrees.

\section{Other Parameters}

Let us now consider other changes that coincide with bitumen, hydrocarbon, and total organic matter content. In Figure 16 the samples are arranged in accordance with the degree of thermal alteration, which is in 


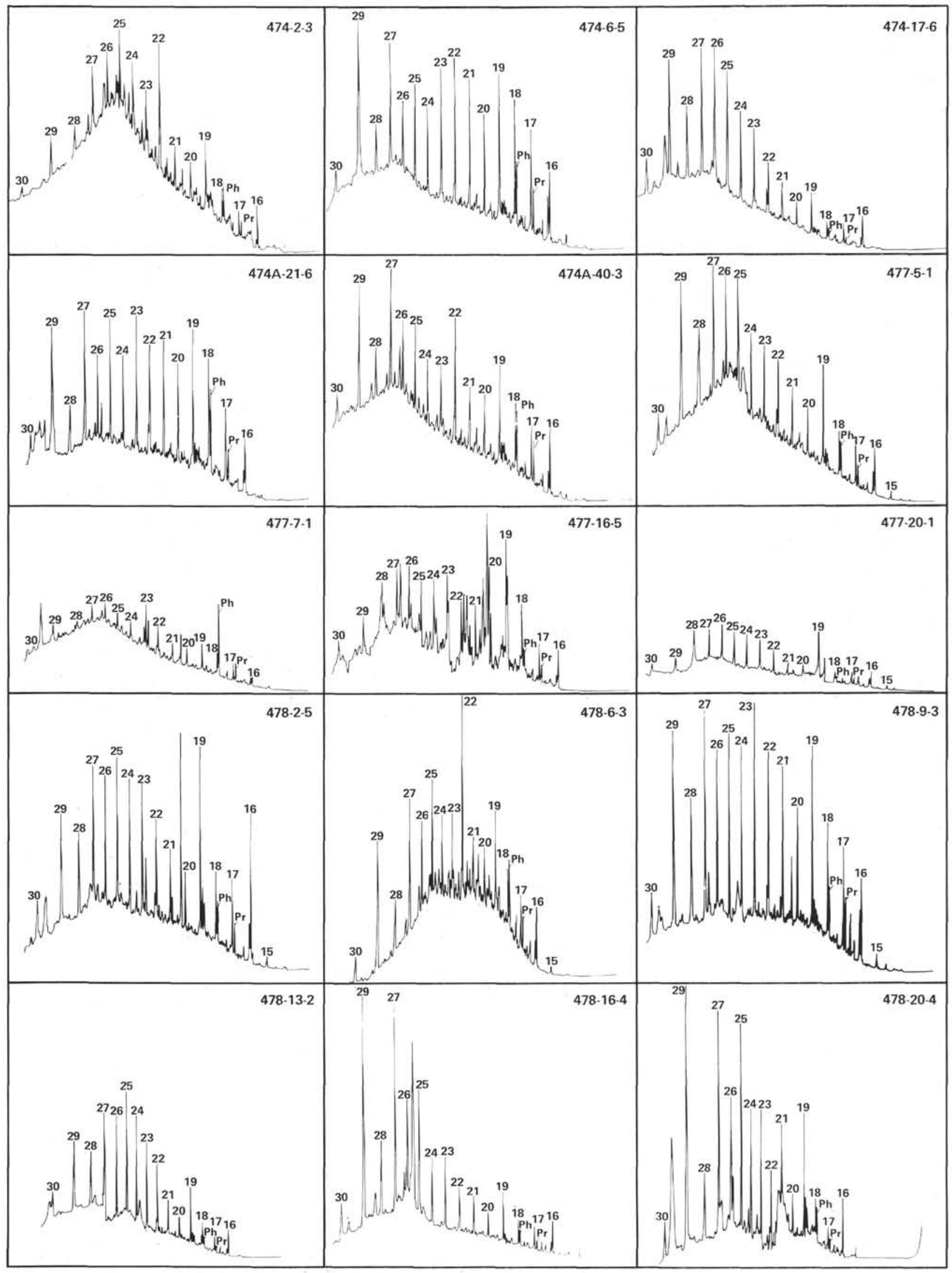

Figure 4. Gas chromatograms of the hydrocarbon fractions from samples of the cores indicated. 


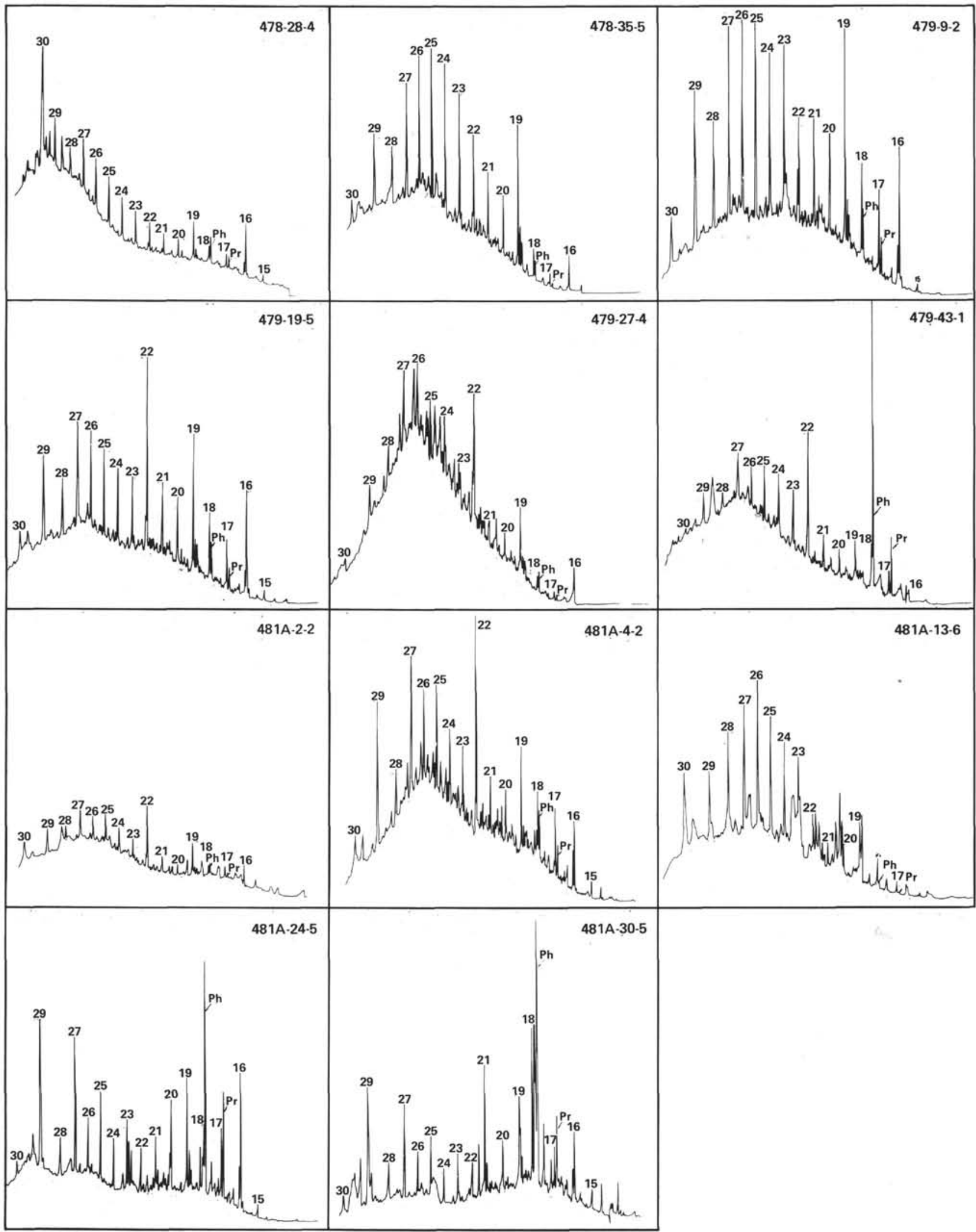

Figure 4. (Continued). 


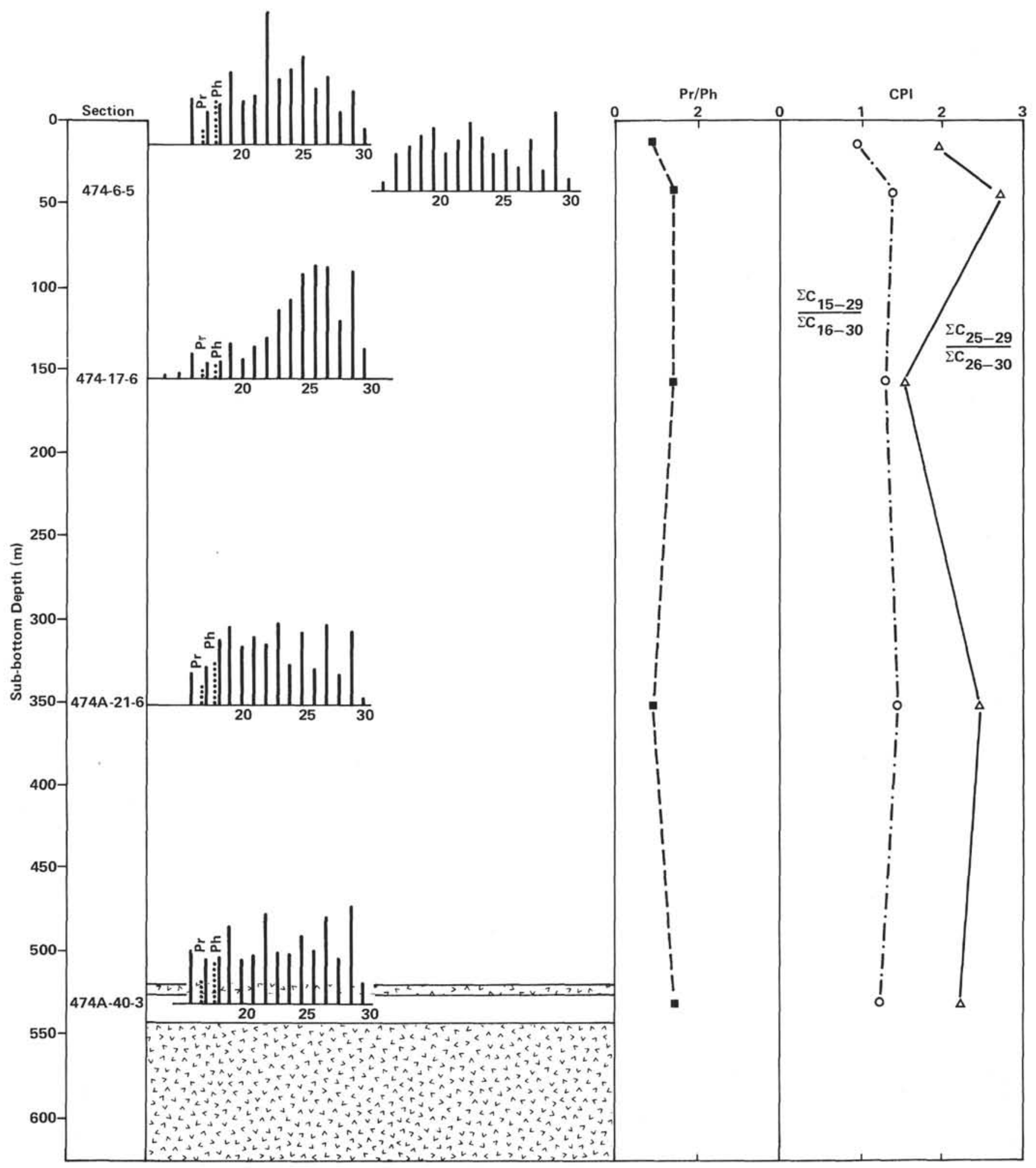

Figure 5. Distribution of alkanes, Holes 474 and $474 \mathrm{~A}$.

the order established by Figure 15. Section $478-6-3$ is used as the background value, since the corresponding deposit was apparently not influenced by thermal stress.

The nature and content of the tetrapyrrole pigments appear to be the most sensitive criteria. Only chlorins are present in the immature sample in Section 478-6-3. Ni-porphyrins appear (in Sections 479-43-1 and 474-
40-3) in samples belonging to the ascending part of the bitumen-hydrocarbon curves. In Section 477-7-1, Niand $\mathrm{Cu}$-porphyrins as well as VO-porphyrins were found. Sections 477-16-5 and 481A-13-6, subjected to overheating, show no pigments.

Alkane distributions exhibit interesting peculiarities. Samples corresponding to the ascending part of the bi- 


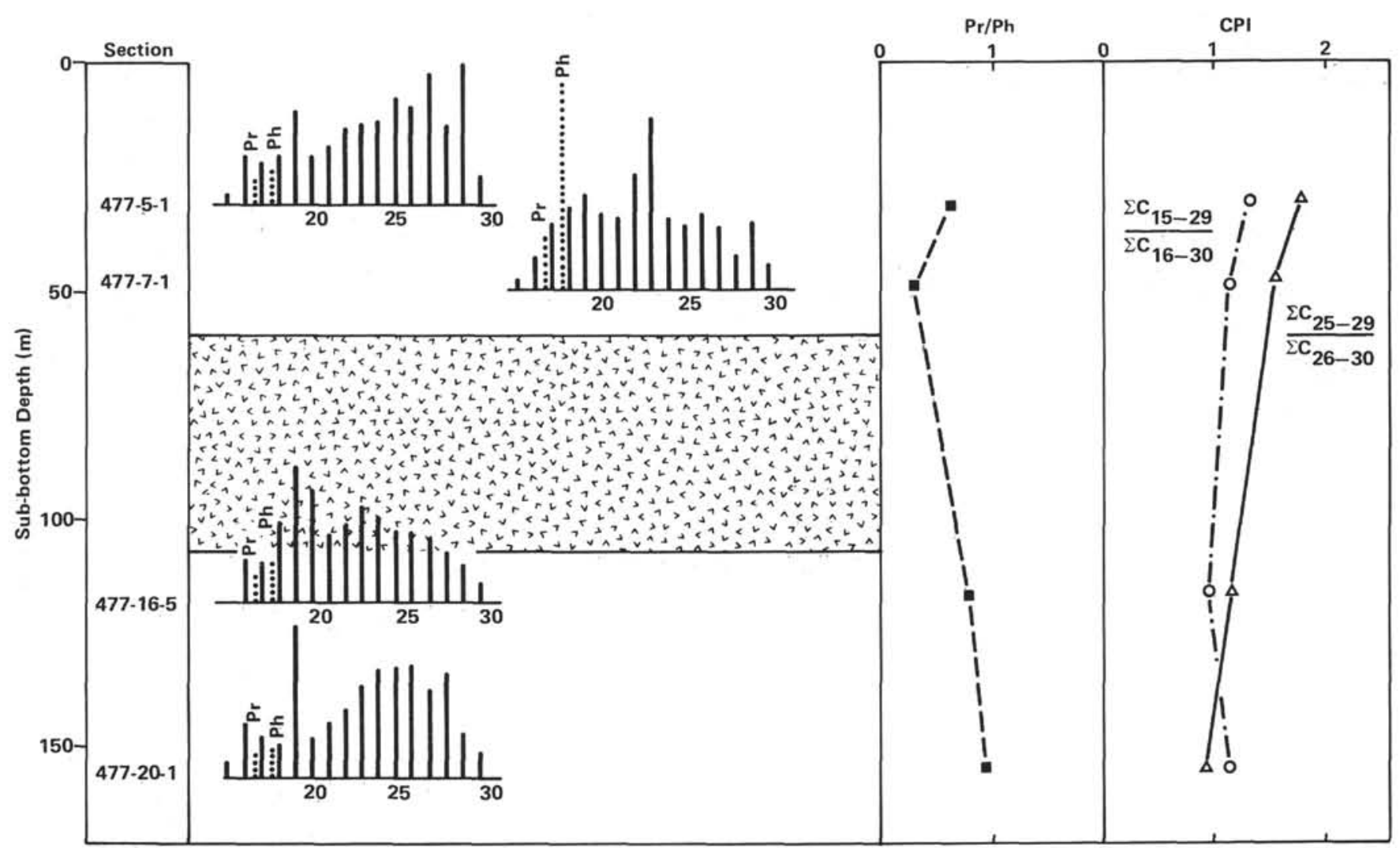

Figure 6. Distribution of alkanes, Hole 477.

tumen-hydrocarbon curves are characterized by alkane distributions that seem to be determined by the source of the organic matter and by sedimentation and diagenetic conditions rather than by thermal effects. However, the picture changes for samples in Sections 477-165 and 481A-13-6 which belong to the descending part of the curves. Both sections are characterized by low values of phytane to $n-\mathrm{C}_{18}$ ratios. The odd/even carbon preference index (CPI) for the high molecular weight $n$-alkanes $\left(\mathrm{C}_{25}+\mathrm{C}_{27}+\mathrm{C}_{29}\right.$ over $\left.\mathrm{C}_{26}+\mathrm{C}_{28}+\mathrm{C}_{30}\right)$ is close to unity. In the chromatograms of the hexane fractions of Sections 477-16-5 and 481A-13-6, there are numerous peaks in the $\mathrm{C}_{19}-\mathrm{C}_{23}$ region (see also Fig. 4). Although these peaks have not yet been identified, they probably indicate the presence of unsaturated and branched or cyclic hydrocarbons in the overheated samples.

The carbon isotope distributions of bitumen fractions from Sections 478-6-3, 479-43-1, 474A-40-3, and 477-7-1 show a regularity which was observed previously (Galimov et al., 1980): ${ }^{12} \mathrm{C}$ depletion in the order hydrocarbons (hexane fraction), hexane-benzene fraction, benzene fraction, benzene-methanol fraction, and asphaltenes. Only Sections $477-16-5$ and $481 \mathrm{~A}-13-6$, in which the carbon isotope compositions are almost equal, show unusual isotope distributions.

These various parameters reveal a change in relation to the degree of thermal stress which is in agreement with expectations for maturation processes. At the same time it should be noted that the results of thermal alteration do not entirely agree with expectations for longtime maturation under moderate temperature conditions. In- deed, the $n$-alkanes of Sections 477-16-5 and 481A-13-6 do not show an odd/even carbon number predominance, as do oil hydrocarbons. On the other hand, these sections do not contain any pigments, whereas crude oils do. From the standpoint of hydrocarbon content, although Section 477-7-1 corresponds to the main phase of oil generation, it seems immature if we consider the relatively high $\mathrm{CPI}, \mathrm{Ph} / n-\mathrm{C}_{18}$, and the presence of $\mathrm{Cu}$ porphyrins.

Apart from the role of thermal effects, the data provide some evidence concerning the source of the organic matter and the conditions of diagenesis.

The carbon isotope composition of the organic matter varies throughout the sections within a range of from -20.46 to $-23.23 \%$. Relatively high $\delta^{13} \mathrm{C}$ values together with a narrow range of variation indicate a predominantly marine source with a rather small and constant input of terrestrial material.

The low values of CPI for all the samples (0.86-2.0), as well as the predominance of $\mathrm{C}_{16}-\mathrm{C}_{19} n$-alkanes, are characteristic of an algal input into sediments (Simoneit et al., 1979). The maximum at $n-C_{22}$ or $C_{23}$, seen on many chromatograms, may be considered evidence of bacterial degradation of algal detritus and remnants of higher plants (Johnson and Calder, 1973). The large hump (especially in Sections 474-2-3, 478-6-3, 479-27-4, 479-43-1, and 481A-4-2) can also be considered evidence of high microbial and algal input to the organic matter. Normal alkanes are not abundant in these sections. The minor contribution of terrigenous organic matter derived from higher plants is clear in chromatograms max- 


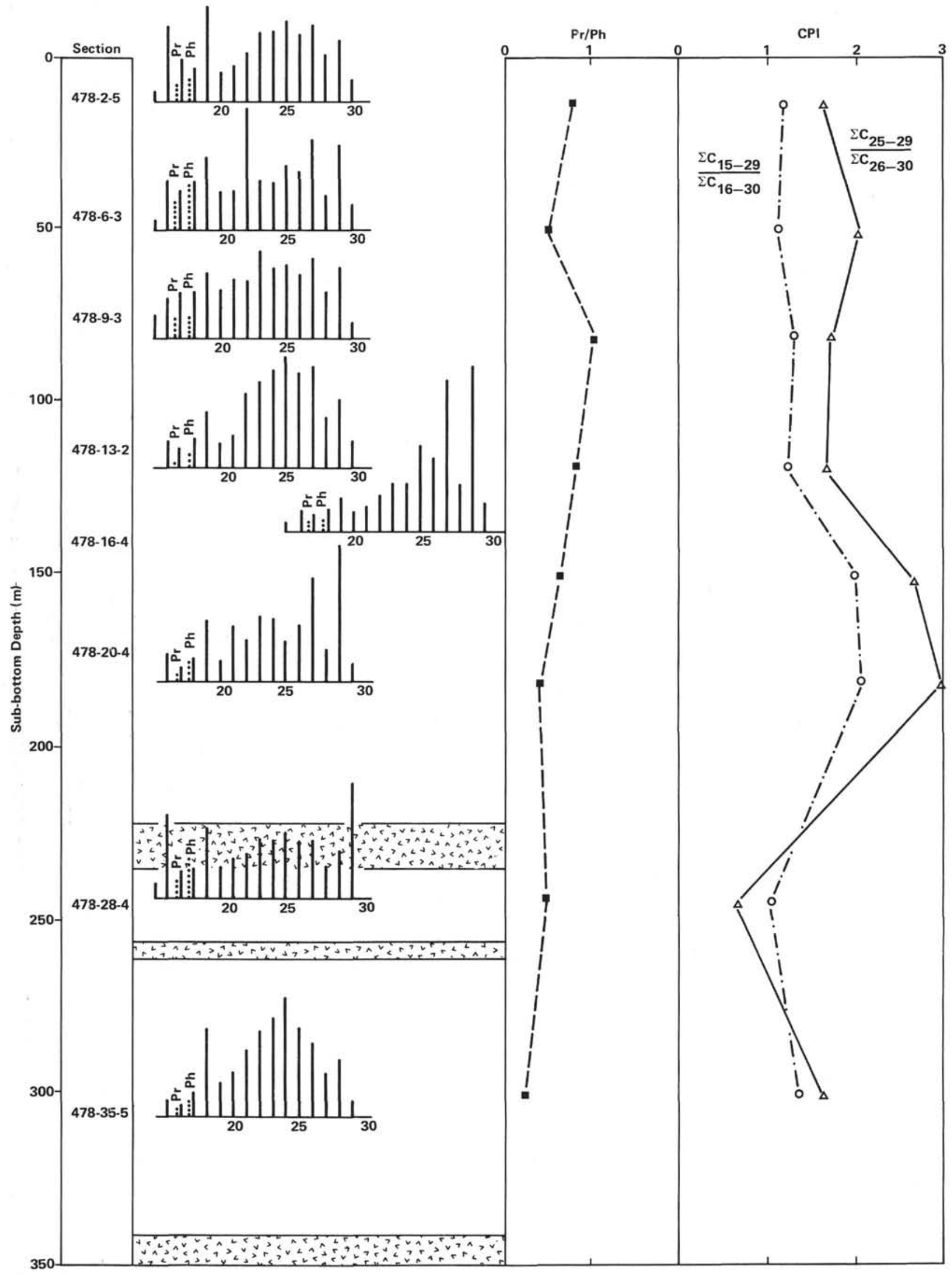

Figure 7. Distribution of alkanes, Hole 478. 
ORGANIC GEOCHEMICAL STUDIES

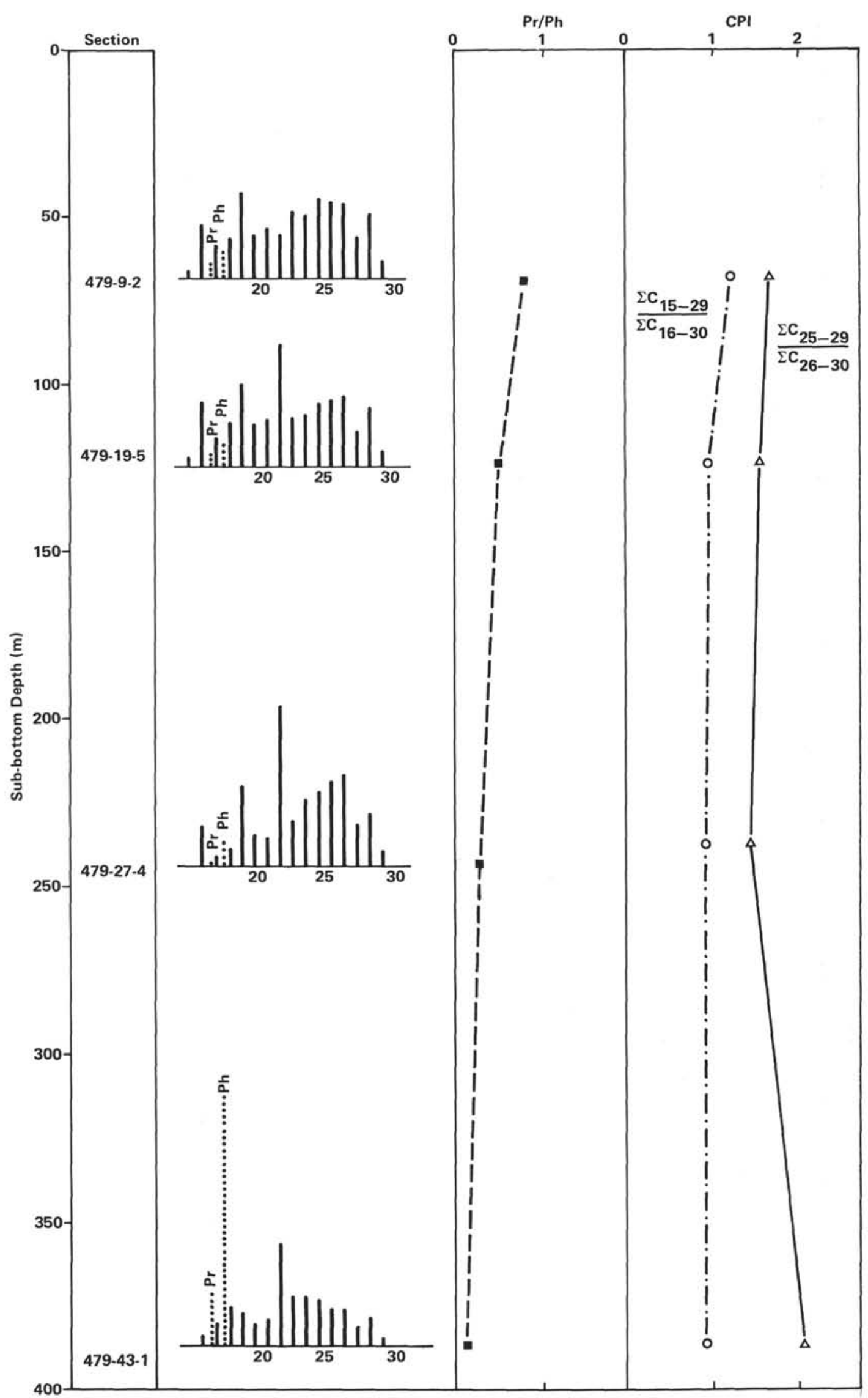

Figure 8. Distribution of alkanes, Hole 479. 


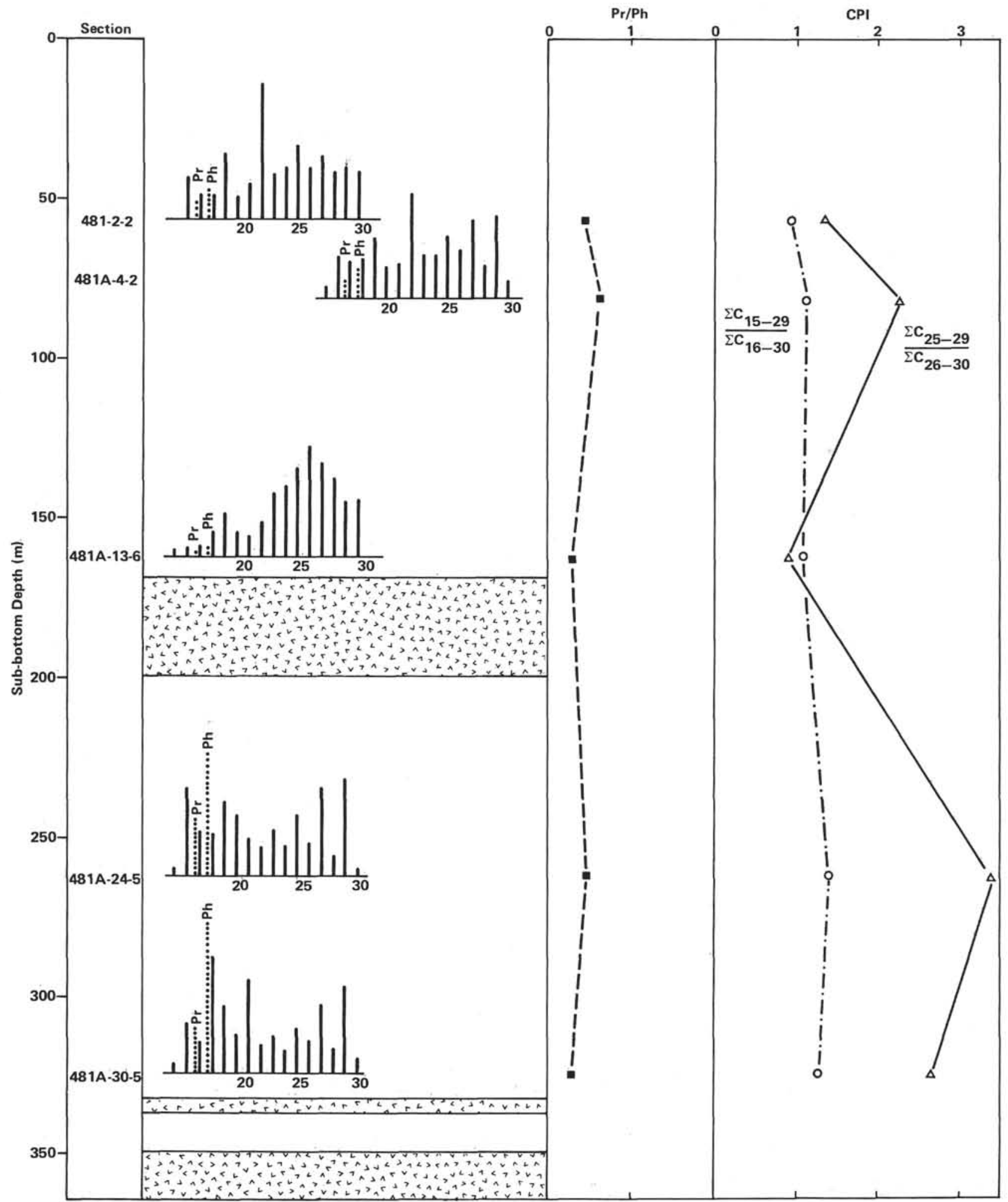

Figure 9. Distribution of alkanes, Hole 481A.

imizing at $\mathrm{C}_{27}-\mathrm{C}_{29}$ (Eglinton and Hamilton, 1963), with a rather high value of CPI (to 3.45 ) for the $n$-alkanes ranging from $\mathrm{C}_{25}$ to $\mathrm{C}_{30}$.

The content of isoprenoids (pristane and phytane) is on the average rather high ( $2-10 \%$ of the total alkanes), with values as high as 30 -and up to $56 \%$-in several sections (477-7-1, 479-43-1, 481A-24-5, 481A-30-5). The pristane-to-phytane ratio varies from 0.20 to 1.02 . Low values of the $\mathrm{Pr} / \mathrm{Ph}$ may be considered as evidence of anoxic diagenesis (Didyk et al., 1978). Hole 479 is especially significant in this respect. In three of four cores from this hole, a high predominance of $n-\mathrm{C}_{22}$ alkane is observed. This may be ascribed to anaerobic microbial activity (Johnson and Calder, 1973). 
Table 3. Visible light absorption spectra of bitumen fractions, Holes 474, 474A, 477, 478, 479, 481, and 481A.

\begin{tabular}{|c|c|c|c|c|}
\hline Section & $\begin{array}{l}\text { Sub-bottom } \\
\text { Depth } \\
\text { (m) }\end{array}$ & $\begin{array}{l}\text { Bitumen } \\
\text { Fraction }\end{array}$ & $\begin{array}{c}\text { Visible Light } \\
\text { Absorption Spectra } \\
\lambda_{\max }(\mathrm{nm})\end{array}$ & Compounds \\
\hline \multicolumn{5}{|c|}{ Hole 474} \\
\hline $\begin{array}{r}2-3 \\
6-5 \\
17-6\end{array}$ & $\begin{array}{l}6.2-6.5 \\
46-46.3 \\
153-153.25\end{array}$ & $\begin{array}{l}\text { Hexane-benzene } \\
\text { Hexane-benzene } \\
\text { Hexane-benzene }\end{array}$ & $\begin{array}{l}395,520,555 \\
395,515,552 \\
395,520,554\end{array}$ & $\begin{array}{l}\text { Ni-porphyrins, trace } \\
\text { Ni-porphyrins, trace } \\
\text { Ni-porphyrins }\end{array}$ \\
\hline \multicolumn{5}{|c|}{ Hole 474A } \\
\hline $\begin{array}{l}21-6 \\
40-3\end{array}$ & $\begin{array}{c}351.98-352.28 \\
528.7-529.0\end{array}$ & $\begin{array}{l}\text { Hexane-benzene } \\
\text { Hexane-benzene }\end{array}$ & $\begin{array}{l}395,520,553 \\
395,520,553\end{array}$ & $\begin{array}{l}\text { Ni-porphyrins } \\
\text { Ni-porphyrins }\end{array}$ \\
\hline \multicolumn{5}{|c|}{ Hole 477} \\
\hline $\begin{array}{l}5-1 \\
7-1\end{array}$ & $\begin{array}{c}30.7-30.9 \\
49.82-49.92\end{array}$ & $\begin{array}{l}\text { Hexane-benzene } \\
\text { Hexane-benzene } \\
\text { Benzene } \\
\text { Hexane-benzene } \\
\text { Benzene-methanol }\end{array}$ & $\begin{array}{l}400,590-610,654 \\
400-402,522,553, \\
562 \\
408,532,570 \\
\text { No bands } \\
\text { No bands }\end{array}$ & $\begin{array}{l}\text { Chlorins } \\
\text { Ni-porphyrins, } \\
\text { Cu-porphyrins } \\
\text { vo-porphyrins } \\
\text { No pigment } \\
\text { No pigment }\end{array}$ \\
\hline \multicolumn{5}{|c|}{ Hole 478} \\
\hline $6-3$ & $45.7-46.0$ & Hexane-benzene & $\begin{array}{l}400-410,550-560 \\
600,656 \\
400-410,560,600 \\
650\end{array}$ & Chlorins \\
\hline $\begin{array}{r}9-3 \\
16-4 \\
20-4 \\
28-4\end{array}$ & $\begin{array}{c}74.1-74.4 \\
142.2-142.5 \\
170.5-170.9 \\
248.2-248.5\end{array}$ & $\begin{array}{l}\text { Hexane-benzene } \\
\text { Hexane-benzene } \\
\text { Hexane-benzene } \\
\text { Hexane-benzene } \\
\text { Benzene } \\
\text { Hexane-benzene }\end{array}$ & $\begin{array}{l}550-560,600,654 \\
395,520,552 \\
395,520,553 \\
396,520,553,585 \\
404,588 \\
395,520,552\end{array}$ & $\begin{array}{l}\text { Chlorins } \\
\text { Ni-porphyrins } \\
\text { Ni-porphyrins } \\
\text { Ni-porphyrins } \\
\text { Ni-porphyrins (rhodo-type?) } \\
\text { Ni-porphyrins }\end{array}$ \\
\hline \multicolumn{5}{|c|}{ Hole 479} \\
\hline $\begin{array}{r}9-2 \\
19-5 \\
27-4\end{array}$ & $\begin{array}{c}72.15-72.40 \\
171.6-171.9 \\
246.25-246.50\end{array}$ & $\begin{array}{l}\text { Hexane-benzene } \\
\text { Hexane-benzene } \\
\text { Hexane-benzene } \\
\text { Benzene } \\
\text { Hexane-benzene }\end{array}$ & $\begin{array}{l}\text { No bands } \\
395,522,555 \\
395,522,553 \\
400,522,556,585 \\
397,520,554\end{array}$ & $\begin{array}{l}\text { No pigment } \\
\text { Ni-porphyrins } \\
\text { Ni-porphyrins } \\
\text { Ni-porphyrins } \\
\text { Ni-porphyrins }\end{array}$ \\
\hline \multicolumn{5}{|c|}{ Hole 481A } \\
\hline $\begin{array}{r}2-2 \\
4-2 \\
13-6 \\
24-5\end{array}$ & $\begin{array}{l}57.75-58.0 \\
73.10-73.40 \\
162.0-162.14 \\
267.6-268.0\end{array}$ & $\begin{array}{l}\text { Hexane-benzene } \\
\text { Hexane-benzene } \\
\text { Hexanc-benzene } \\
\text { Hexane-benzene } \\
\text { Benzene } \\
\text { Hexane-benzene } \\
\text { Benzene }\end{array}$ & $\begin{array}{l}410,600,654 \\
395,520,555 \\
\text { No bands } \\
395,520,552 \\
395,520,552 \\
395,520,553 \\
400,586\end{array}$ & $\begin{array}{l}\text { Chlorins } \\
\text { Ni-porphyrins } \\
\text { No pigments } \\
\text { Ni-porphyrins } \\
\text { Ni-porphyrins } \\
\text { Ni-porphyrins } \\
\text { Ni-porphyrins (rhodo-type }\end{array}$ \\
\hline
\end{tabular}

\section{ACKNOWLEDGMENTS}

We thank Dr. B. Simoneit and Prof. A. B. Ronov for reviewing the manuscript and improving our English and the staff of DSDP and the National Science Foundation for making the samples available. We wish also to acknowledge the assistance of L. Ye. Shishmareva, V. N. Generalowa, and E. N. Ivanov.

\section{REFERENCES}

Baker, E. W., Palmer, S. E., and Huang, W. I., 1978. Intermediate and late diagenetic tetrapyrrole pigments, Leg 41: Cape Verde Rise and Basin. In Lancelot, Y., Seibold, E., et al., Init. Repts. DSDP, 41: Washington (U.S. Govt. Printing Office), 825-837.

Baker, E. W., Palmer, S. E., and Parrish, K. L., 1976. Tetrapyrrole Pigments in DSDP Leg 38 Sediments. In Talwani, M., Udintsev, G., et al., Init. Repts. DSDP, 38: Washington (U.S. Govt. Printing Office), 785-790.

Didyk, B. M., Simoneit, B. R. T., Brassell, S. C., et al., 1978. Organic geochemical indicators of palaeoenvironmental conditions of sedimentation. Nature, 272:216-222.

Dow, W. G., 1978. Contact metamorphism of kerogen in sediments from Leg 41: Cape Rise and Basin. In Lancelot, Y., Seibold, E., et al., Init. Repts. DSDP, 41: Washington (U.S. Govt. Printing Office), 821-824.

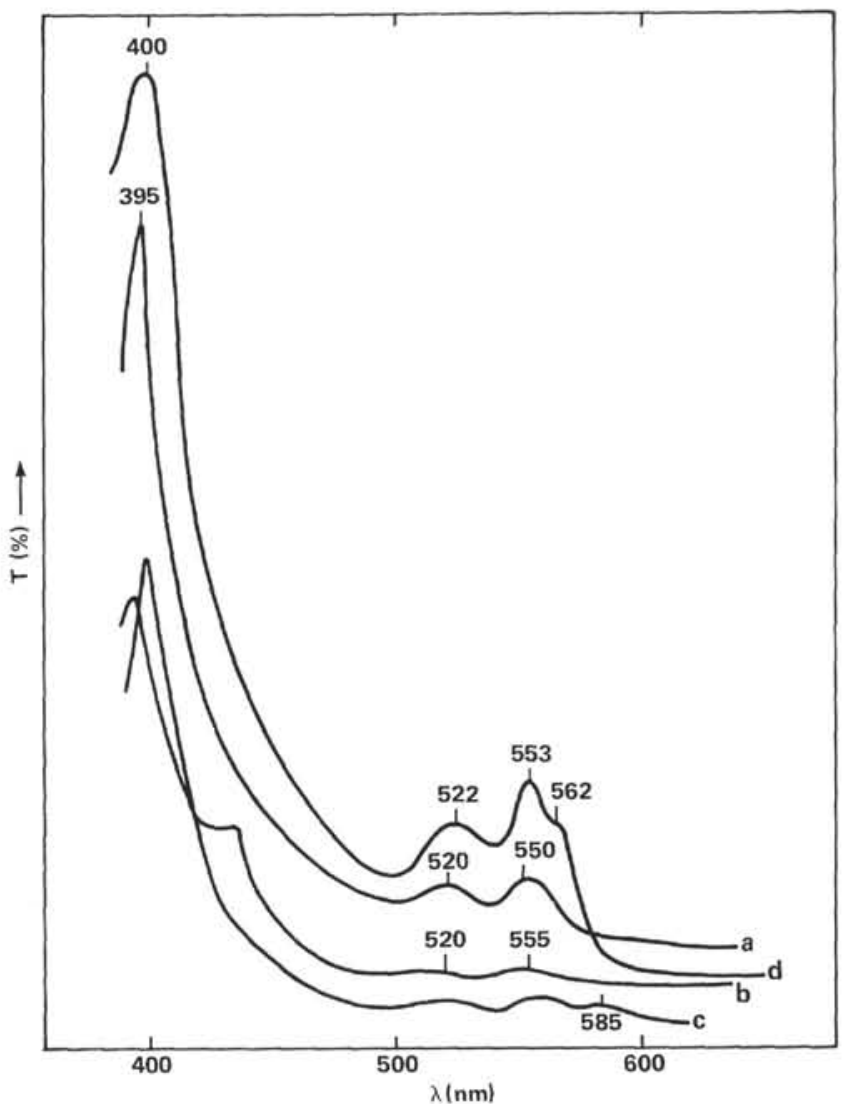

Figure 10.Visible light absorption spectra of bitumen fractions. (a, Hexane-benzene fraction, Section 474-17-6; b, hexane-benzene fraction, Section 474-2-3; c, benzene fraction, Section 474-27-4; d, hexane-benzene fraction, Section 477-7-1.)

Eglinton, G., and Hamilton, R. J., 1963. The distribution of alkanes. In Swain, T. (Ed.), Chemical Plant Taxonomy: New York (Academic Press), pp. 187-217.

Einsele, G., Gieskes, J. M., Curray, J., et al., 1980. Intrusion of basaltic sills into highly porous sediments, and resulting hydrothermal activity. Nature, 283:441-445.

Galimov, E. M., Kodina, L. A., Shirinsky, V. G., et al., 1980. A study of organic matter from deep oceanic bore holes, Deep Sea Drilling Project Sites 415 and 416, in the Moroccan Basin. In Lancelot, Y., Winterer, E. L., et al., Init. Repts. DSDP, 50: Washington (U.S. Govt. Printing Office), 575-600.

Johnson, R. W., and Calder, J. A., 1973. Early diagenesis of fatty acids and hydrocarbons in a salt marsh environment. Geochim. Cosmochim. Acta, 37:1943-1955.

Perregaard, J., and Schiener, E. J., 1979. Thermal alteration of sedimentary organic matter by a basalt intrusive (Kimmeridgian shales, Milne Land, East Greenland). Chem. Geol., 26:331-343.

Simoneit, B. R. T., Brenner, S., Peters, K. E., et al., 1978. Thermal alteration of Cretaceous black shale by basaltic intrusions in the Eastern Atlantic. Nature, 273:501-504.

Simoneit, B. R. T., Mazurek, M. A., Brenner, S., et al., 1979. Organic geochemistry of Recent sediment from Guaymas Basin, Gulf of California. Deep-Sea Res., 26A:879-891. 


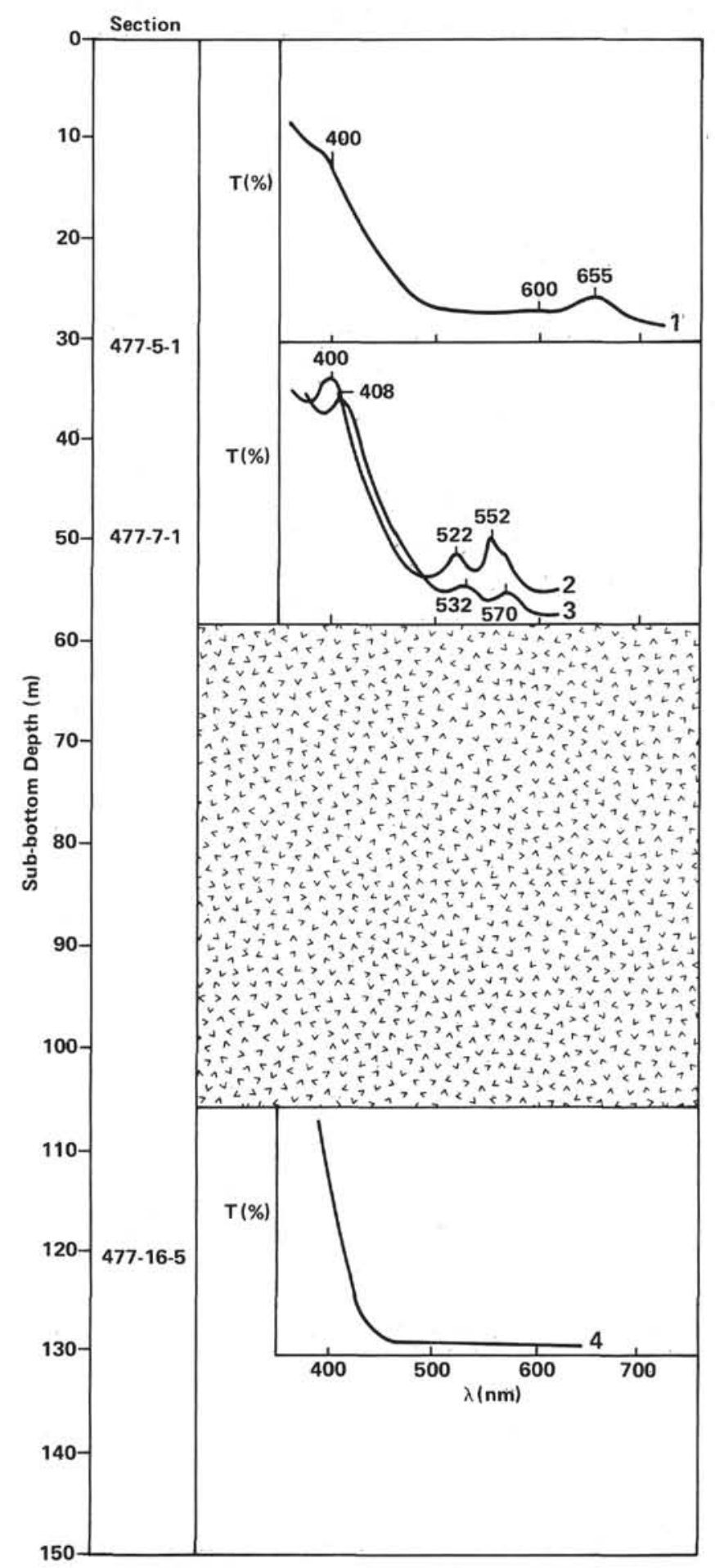

Figure 11. Tetrapyrrole pigments, Hole 477: 1-chlorins, 2-Ni porphyrins, 3-VO-porphyrins, 4-no pigments. 
Table 4. Carbon isotope composition of organic matter, bitumen, and bitumen fractions.

\begin{tabular}{|c|c|c|c|c|c|c|c|c|c|}
\hline \multirow[b]{2}{*}{ Sample } & \multirow[b]{2}{*}{$\begin{array}{l}\text { Sub-bottom } \\
\text { Depth } \\
\text { (m) }\end{array}$} & \multicolumn{2}{|c|}{$\delta^{13} \mathrm{C}(\%)$} & \multirow[b]{2}{*}{$\begin{array}{l}\text { Difference in } \delta^{13} \mathrm{C}(\%) \\
\text { (bitumen and } \\
\text { organic matter) }\end{array}$} & \multicolumn{5}{|c|}{ Fractions } \\
\hline & & $\begin{array}{c}\text { Total } \\
\text { Organic } \\
\text { Matter }\end{array}$ & Bitumen & & Hexane & $\begin{array}{l}\text { Hexane- } \\
\text { Benzene }\end{array}$ & Benzene & $\begin{array}{l}\text { Benzene- } \\
\text { Methanol }\end{array}$ & Asphaltenes \\
\hline
\end{tabular}

Hole 474

$2-3$
$6-5$
$17-6$

$$
\begin{array}{ccc}
6.2-6.5 & -22.25 & -25.23 \\
46-46.3 & -21.77 & -24.85
\end{array}
$$

\section{$-2.98$}

$-3.08$

$-2.29$

Hole 474A

$153-153.25$

$$
351.98-352.28 \quad-21.83 \quad-24.17
$$

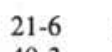

$$
\begin{array}{ll}
-29.70 & -25.92 \\
-28.53 & -25.25 \\
-27.74 & -24.54
\end{array}
$$

$$
\begin{aligned}
& -25.05 \\
& -25.41
\end{aligned}
$$$$
-25.23
$$

$$
-24.51
$$$$
-24.34
$$

$-24.65$

$-24.38$

$-23.41$

$-23.81$

$\begin{array}{llllll}-2.34 & -27.29 & -25.18 & -24.92 & -24.37 & -23.10 \\ -2.27 & -28.07 & -24.97 & -24.95 & -24.10 & -23.03\end{array}$

Hole 477

$\begin{array}{rcrr}5-1 & 30.7-30.9 & -21.82 & -23.94 \\ 7-1 & 49.82-49.92 & -21.84 & -23.38 \\ 16-5 & 121.58-121.88 & -23.23 & -25.35\end{array}$

$20-1 \quad 154.15-154.25 \quad-22.34 \quad-28.08$$$
-24.92
$$

$$
\begin{aligned}
& -2.12 \\
& -1.54 \\
& -2.12
\end{aligned}
$$$$
\begin{array}{r}
-2.12 \\
-5.74
\end{array}
$$$$
\text { (1) }
$$

Hole 478

$\begin{array}{rccc}2-5 & 10.7-11.0 & -21.70 & -24.30 \\ 6-3 & 45.7-46.0 & -21.32 & -24.13 \\ 9-3 & 74.1-74.4 & -21.14 & -23.35 \\ 13-2 & 110.7-111.0 & -21.20 & -22.91 \\ 16-4 & 142.2-142.5 & -21.99 & -23.94 \\ 20-4 & 170.5-170.9 & -22.12 & -23.70 \\ 28-4 & 248.2-248.5 & -22.00 & -23.23 \\ 35-5 & 305.1-305.4 & -22.74 & -24.55\end{array}$

$$
\begin{aligned}
& -2.60 \\
& -2.81 \\
& -2.21 \\
& -1.71 \\
& -1.95 \\
& -1.58 \\
& -1.23 \\
& -1.81
\end{aligned}
$$

$\begin{array}{ll}-28.29 & -25.33 \\ -26.85 & -24.43 \\ -24.57 & -25.14 \\ -28.35^{\mathrm{a}} & \end{array}$

$-25.08$

$-23.82$

$-25.26$

$-23.77$

$-24.55$

$-26.17$

$-23.11$

$-22.22$

$-25.50$

$-28.83$

Hole 479

$\begin{array}{rccc}9-2 & 72.15-72.40 & -21.58 & -23.78 \\ 19-5 & 171.6-171.9 & -21.03 & -23.10 \\ 27-4 & 246.25-246.50 & -20.46 & -22.93 \\ 43-1 & 393.7-393.9 & -23.35 & -25.29\end{array}$

\section{$-2.20$}

$-2.07$

$-2.47$

$-1.94$

-28.47
-29.06
-26.71
-27.31
-26.87
-26.81
-25.57
-28.12

$-26.16$

$-24.35$

$-23.76$

$-24.19$

$-24.34$

$-24.76$

$-24.57$

$-26.21$

$-27.08$

$-25.25$

$-26.38$

$-24.36$

$-24.60$

$-24.47$

$-24.23$

$-24.91$

$-24.09$

$-23.97$

$-23.61$

$-23.46$

$-24.30$

$-23.88$

$-23.85$

$-24.49$

$-23.39$

$-22.72$

$-22.50$

$-22.01$

$-23.14$

$-23.08$

$-22.33$

$-23.08$

Hole 481A

$2-2$
$4-2$
$13-6$
$24-5$
$30-5$

$$
\begin{aligned}
& 57.75-58.0 \\
& 73.10-73.40 \\
& 162.0-162.14 \\
& 267.6-268.0 \\
& 324.6-324.9
\end{aligned}
$$$$
162.0-162.14 \quad-22.97
$$

$-23.08$

$-22.74$

$-24.01$

$$
-24.42
$$

$-23.51$

$-24.89$

$-24.05$

Average values $\delta^{13 C}$ (all determinations)

$-22.04 \quad-24.29$

a Total carbon for hexane, hexane-benzene, benzene, and benzene-methanol fractions. 


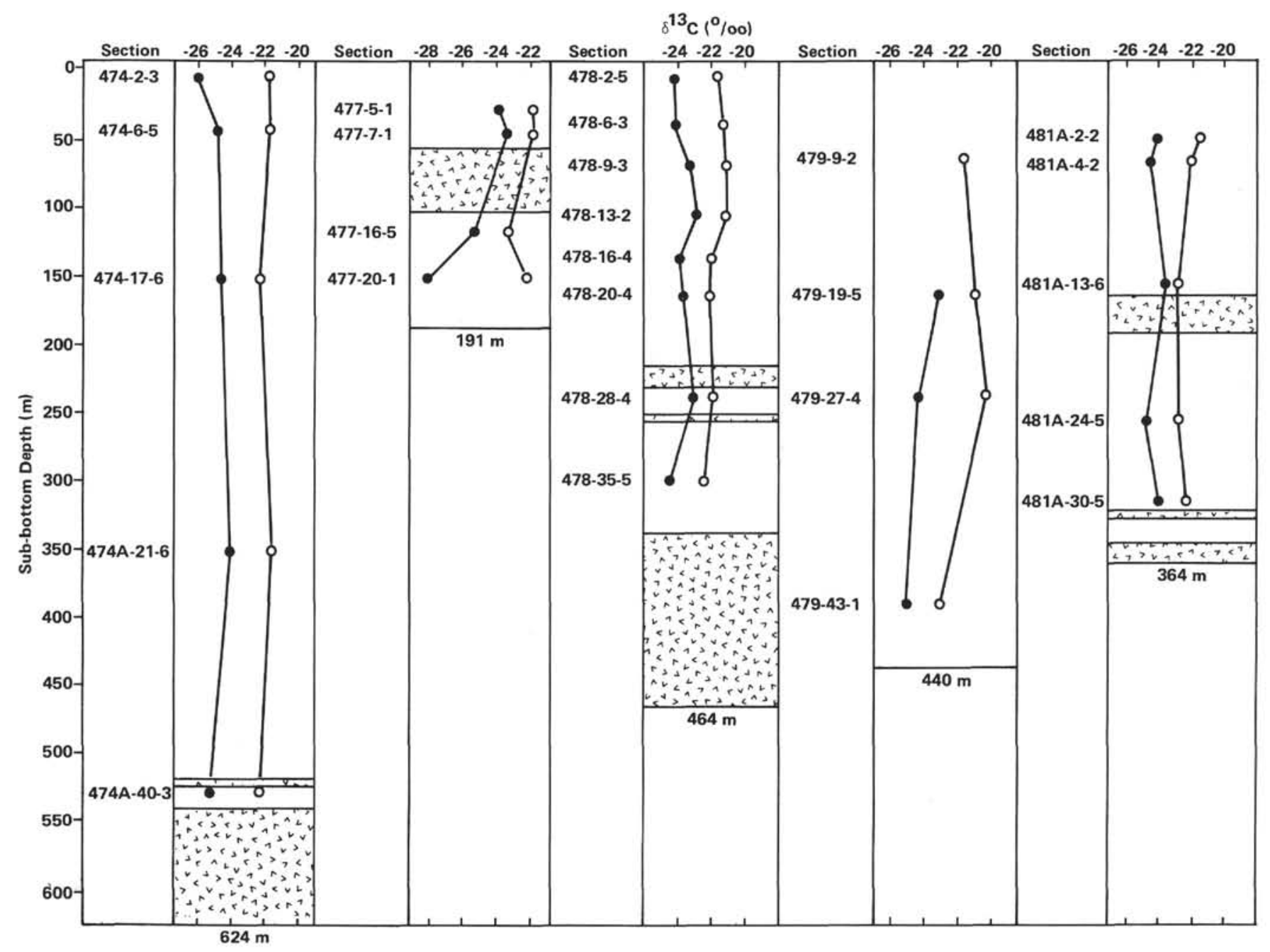

Figure 12. Carbon isotope composition of total organic matter $(O)$ and bitumen ( ). 


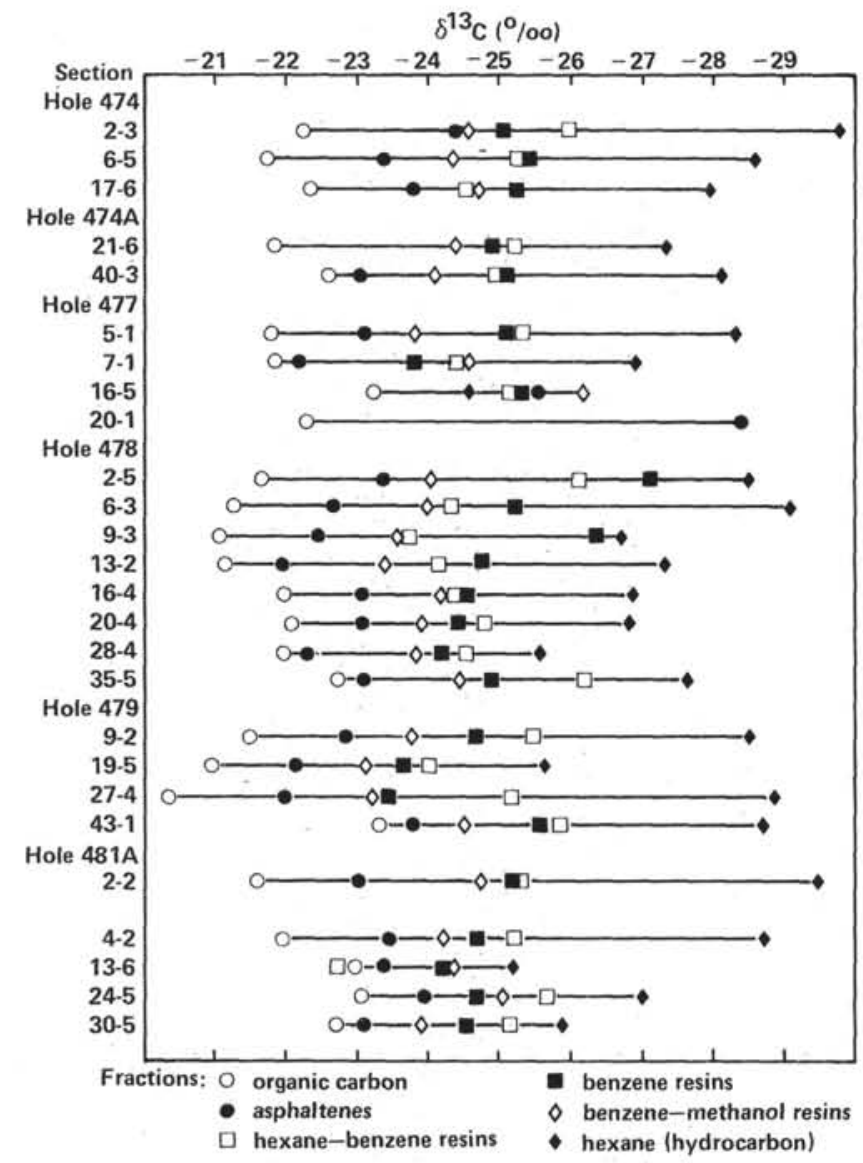

Figure 13. Carbon isotope composition of bitumen fractions and total organic matter.

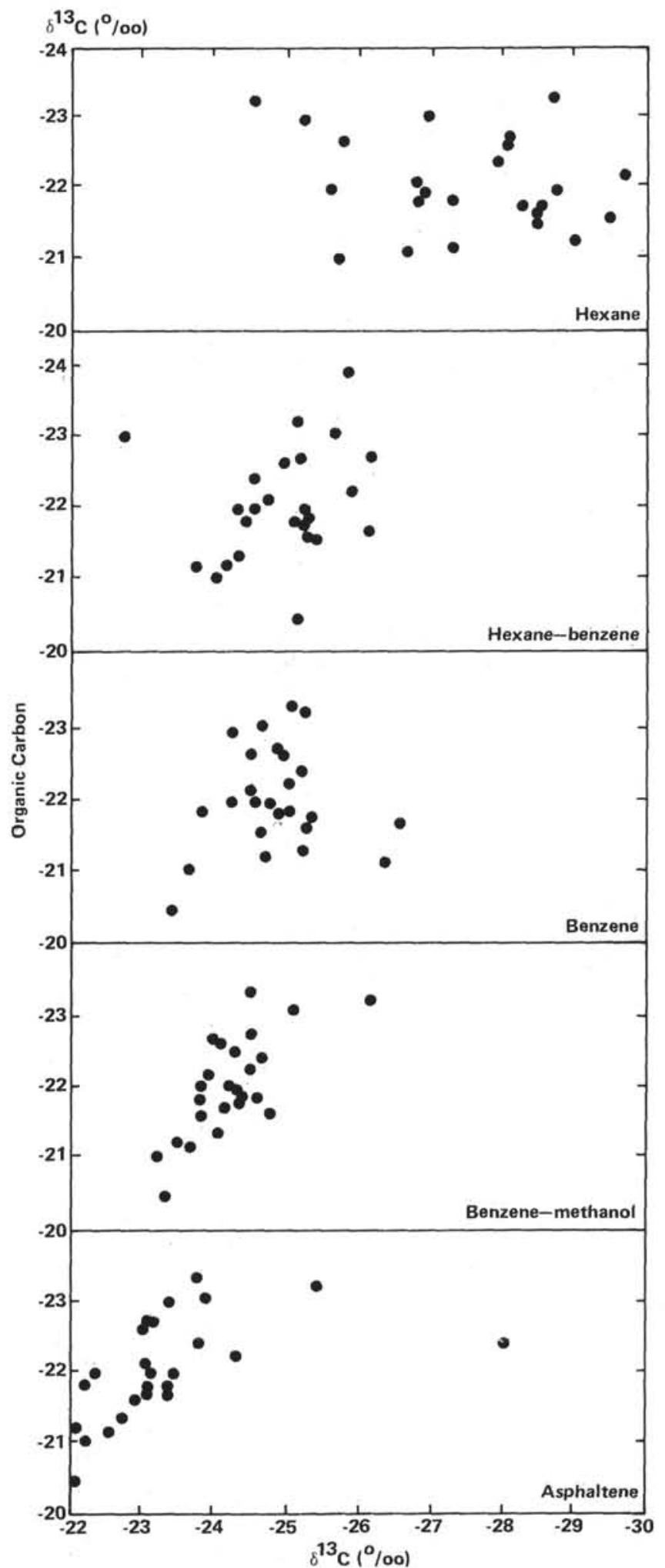

Figure 14. Correlation between carbon isotope composition of total organic matter and different bitumen fractions. 


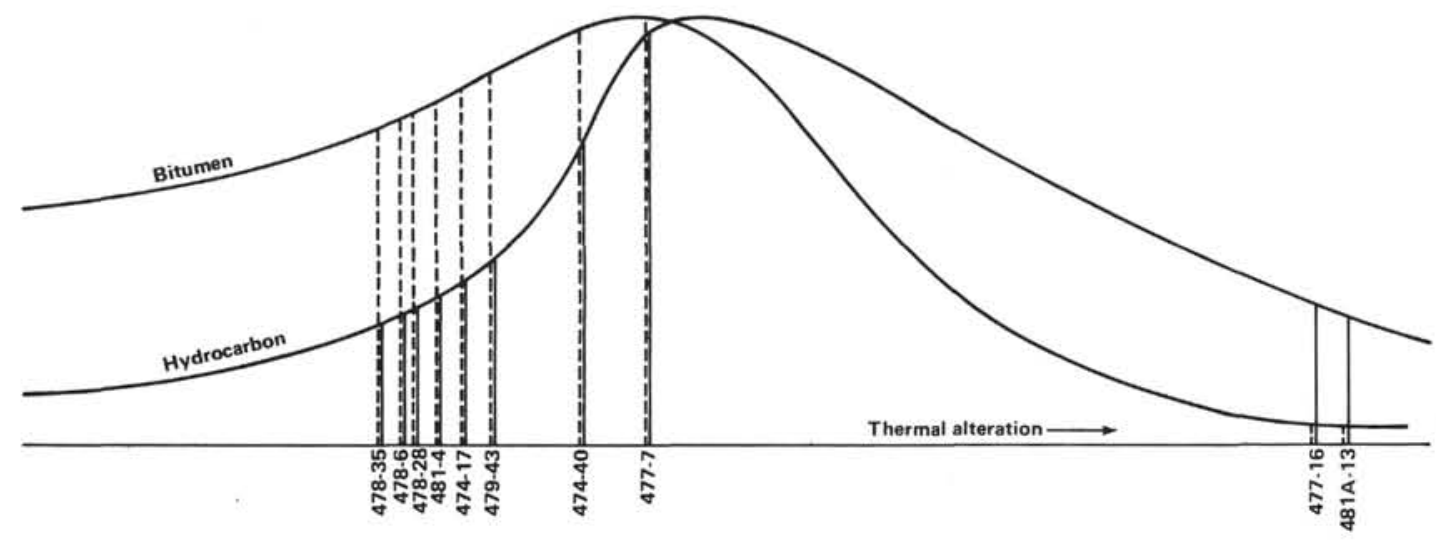

Figure 15. Trends of change in bitumen and hydrocarbon content with increase of thermal alteration.

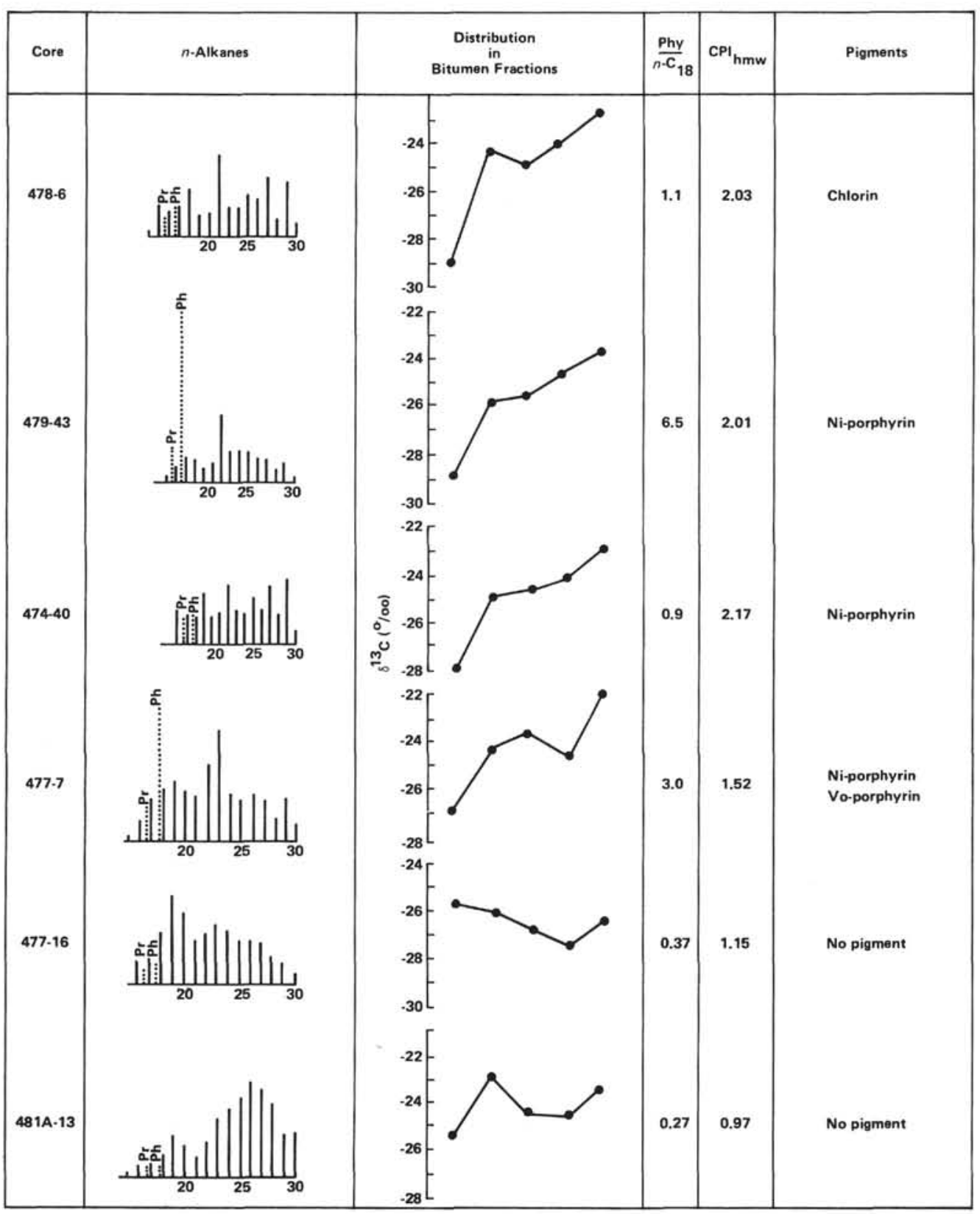

Figure 16. Changes in parameters characterizing thermal alteration of organic matter. 